\title{
A COMPLETE PATHOLOGICAL INVESTIGATION OF THREE CASES OF ACUTE LYMPHOCYTH ÆMIA.
}

\author{
By Leonard S. Dudgeon, M.R.C.P., Director of the Hospital Labora- \\ tories, St. Thomas's Hospital; W. L. HaRnet, M.A., M.B., B.C. \\ (Cantab.), F.R.C.S., Assistant Director of the Pathological Labora- \\ tory; and P. N. Pavton, M.A., M.B., B.C.(Cantab.), Assistant \\ Director of the Louis Jenner Clinical Laboratory, St. Thomas's \\ Hospital, London.
}

From the Pathological Department, St. Thomas's Hospital, London.

\section{(Plate XXXIV.)}

WE have subjected three cases of acute lymphocythæmia to a complete pathological investigation, and now wish to record our observations made on this most interesting disease.

\section{CASE I.}

Clinical History.-W. H., a shop boy, rt. 19, was admitted to St. Thomas's Hospital on 3rd April 1905, under the care of Dr. Hawkins. He had always enjoyed good health until three weeks previously, when he began to have repeated attacks of epistaxis, accompanied by headache. One week before admission he noticed a rash about his body and limbs. On arrival at the hospital he was found to be pale and badly nourished; there were a number of small petechial spots over the limbs and trunk. The tongue was clean, and there was no sponginess of the gums. Both liver and spleen were uniformly enlarged, the former extending $2 \mathrm{in}$, and the latter 1 in. below the costal margin. A very few slightly enlarged glands were felt on both sides of the neck. The optic discs were pale, slightly swollen, and their edges indistinct, but no retinal hæmorrhages were detected until'19th May. With the exception of a cardiac murmur, apparently "hæmic" in origin, no other abnormal physical signs were detected. During his stay in hospital there were repeated hæmorrhages from the nose, and fresh petechial spots continued to appear. On 27th May blood appeared in the urine, and continued in small amount until his death on 4th June. The temperature was raised throughout the course of the illness, varying from $103^{\circ} \mathrm{F}$. in the evenings to $98^{\circ} \mathrm{F}$. in the mornings.

The treatment adopted, other than hæmostatic, was the administration of arsenic and the application of the X-rays, but with the exception of a temporary improvement during the first few days of the X-ray treatment, the improvement being accompanied by a decrease in the number of leucocytes in the blood, the disease continued to progress steadily.

Post-mortem Examination, by Mr. A. E. Mavrogordato. 
ExtrRnal Appearances,-The body was very wasted, and there was much pigmentation of the skin, especially in the axillm and groins.

INTERNAL ExAMINATION.-The upper respiratory passages were normal, but the glande along the trachea and vessels of the neck were enlarged and succulent.

Pleuro..-There were adhesions at left apex, otherwise the sacs were healthy. Lungs (right 18 oz., left 15 oz.). There was soms œdema, otherwise nothing abnormal was seen. The mediastinal glands were enlarged, and one at the bifurcation of the trachea was found to have broken down.

Heart (weight $12 \mathrm{oz}$. ). Pericardium.-The epicardium and pericardium were covered with petechial hæmorrhages, which also extended down into the muscular substance of the heart. The heart valves were normal.

Abdomen.- Lymphatic glands along the whole length of the abdominal aorta were found to be enlarged. The liver (weight $54 \mathrm{oz}$.) was soft and pale, and failed to give any free iron reaction. The kidneys (weight 12t oz.) were large and pale, but otherwise showed nothing abnormal. The free iron reaction was not obtained. The spleen (weight $13 \mathrm{oz}$.) was large and tough, and no free iron reaction was obtained. The intestinal tract was normal. The mesenteric glands were enlarged, but not reddened. The suprarenal capsules were pale.

The brain (weight 45 oz.) appeared to be normal.

The bone marrow, exposed in the femur and ribs, showed nothing abnormal to the naked eye.

Histological Examination.-Kidney/8.-The capsule and glomeruli appeared to be normal. Many of the epithelial cells in the convoluted and straight tubules were swollen and presented an irregular outline, their protoplasm was granular and their nuclei faintly stained; there was a considerable amount of epithelial desquamation into the lumina of the tubules. Both in and around the vessels were collections of cells, consisting mainly of small and large lymphocytes and large hyaline cells, together with a few plasma cells. Large cells with small deeply staining nuclei and a considerable quantity of finely granular oxyphil cytoplasm were scattered throughout the sections. Tailed forms of fibroblasts were absent. On the whole the cellular infiltration observed was slight in amount.

Adrenals. - The capsule, the glandular cells, and the vessels showed nothing abnormal. Cellular infiltration was very slight, but was present in a few small areas of the connective tissue; the cells were composed of large and small lymphocytes and large hyaline cells, together with an occasional plasma cell and a few oxyphil mononuclear cells similar to those described in the kidney.

Liver. - The hepatic cells were found to be in all stages of degeneration, and throughout the sections vacuolation of the cells was very marked. Very slight golden brown pigmentation was also observed. The capsule was normal. In the portal spaces and between the hepatic cells were collections of cells, similar in all respects to these described in the kidney, and here again the cellular infiltration present was of very moderate extent.

Spleen.-The capsule was normal. Fibrosis of the Malpighian bodies was very well marked. The small lymphocytes were scanty, large lymphocytes, large hyaline and endothelial cells predominating; in addition there were present in very small numbers transitional cells, plasma cells, and the finely granular oxyphil cells already referred to. Numerous unclassified cells were also present in the sections, which were stained by Leishman's method. No coarsely granular eosinophil nor polynuclear cells were seen. Fragmentation of nuclei was well marked in many cells, but very few mitotic figures were observed. No engulfing of red cells seen; no parasites or micro-organisms found. Multinucleated cells were very scarce.

Lymphatic gland.-The histological structure was similar to that of the 
Results of Examination of Blood.

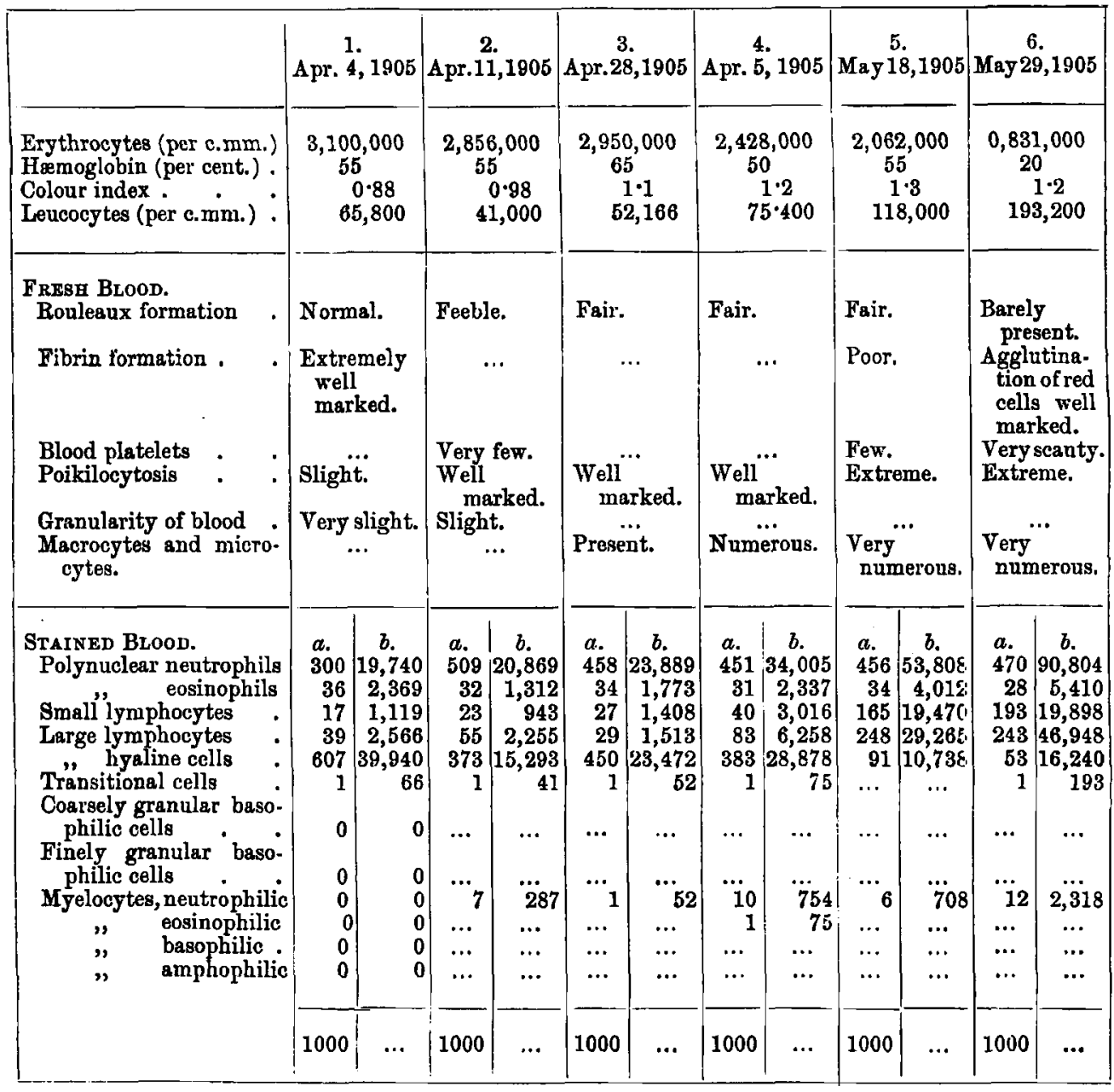

\section{$a=$ Total number of cells counted.}

To obtain percentages divide the figure in the first column $a$ by $10-e . g . \frac{300}{10}=30$ or $\frac{36}{10}=3 \cdot 6$, etc.

In every histological examination of blood and bone marrow reported in this communication the differential count of cells was made by the same observer; a point of considerable importance.

\section{NOTES ON STAINED BLOOD.}

1. Polychromatophilia well marked. Numerous red cells showed both coarse and fine granular degeneration. Macrocytes and microcytes present. Nine normoblasts and eight megaloblasts seen during a count of 1000 white cells. The large majority of the large hyaline cells described above were coargely vaciolated, and most of the polynuclear neutrophils contained no granules. An identical result was also obtained with Ehrlich's triacid stain.

2. Polychromatophilia well marked. Granular degeneration slight. Macrocytes and microcytes numerous. Four normoblasts and seven megaloblasts seen during a count of 1000 white cells. Most of the larre hyaline cells contained wellmarked vacuoles. A differential count by Ehrlich's triacid stain gave an almost identical resuli.

3. Polychromatophilia and granular degeneration present. Twenty-four normohlasts and one megaloblast seen while counting 1000 leucocytes. The large proportion of the large byaline cells showed coarse vacuoles. The polynuclear neutrophils were very slightly granular.

4. Polychromatophilia and granular degeneration well marked. Sixteen nomoblasts, fourteen megaloblasts, and two microblasts seen during a count of 1000 leucocytes. Large hyaline cells showed coarse vacuoles tor the most part. The large majority of the polynuclears contained few or no granules.

5. Polychromatophilia and granular degeneration extreme. Sixteen normoblasts, eight megaloblasts, and four microblasts seen in counting 1000 leucocytes. Vacuolar change in the large hyaline cells very slight. Most of the polynuclears were without granules.

6. Thirty-five normoblasts, thirteen megaloblasts, and two microblasts seen during a count of 1000 leucocjtes. Polychromatophilia and granular degeneration well-marked. 
spleen, the notable feature being the replacement of the small lymphocytes by various large cells. The capsule was normal, and no fibrosis of the gland tissue was found.

The above tissues were examined micro-chemically for the presence of free iron, but in all cases with a negative result.

\section{CASE II.}

Clinical History.-H. B., a printer's labourer, æt. 17, was admitted to St. Thomas's Hospital on 13th June 1905, under the care of Dr. Sharkey, and died three days later. The family history and past history were unimportant. On 12th May the patient first complained of dizziness and headache, which prevented him going to work for twenty-four hours. On 6 th June the symptoms returned, and were followed by vomiting two days later. For three weeks before admission he suffered from dyspnca on exertion, and weakness. On 9th June he noticed a lump in the left side of the abdomen which gave him severe pain. On 10th June he had an attack of epistaxis, which recurred several times up till the date of admission; there was no bleeding from the gums. The patient had noticed enlarged glands in the axillæ for "some time," but could not remember how long. On examination he was found to be a somewhat anæmic looking boy, with a temperature of $101^{\circ} \mathrm{F}$. The tongue was furred and moist, and there was bleeding from the gums. Over the front of the chest and back numerous petechiz were present. There was no tenderness of the long bones. In the neck, axillæ, and groins numerous enlarged fairly soft glands were felt; they were freely movable both on the skin and in the underlying structures.

The pulse was 120 . The heart and lungs were normal.

The abdomen moved well on respiration; the spleen extended downwards to one inch below the level of the umbilicus, and the splenic dulness extended upwards to the seventh rib in the mid-axillary line. The free margin of the liver couid be felt as low as the umbilicus, and the hepatic dulness extended upwards to the fifth rib in the nipple line. The knee-jerks were normal. The optic discs were blurred, and numerous retinal hæmorrhages were present.

The urine was acid, the specific gravity 1012 , and there was no albumin, blood, or sugar. There was a heavy deposit of urates.

While in the hospital the patient's temperature varied from $101^{\circ} \mathrm{F}$. in the morning to $104^{\circ} \cdot 2 \mathrm{~F}$. in the evening. He was restless, and complained of splenic pain ; there was some bleeding from the nose and gums.

Post-mortem Examination, by Mr. Mavrogordato.

Extennally the body was found to be well nourished.

The mouth was not obviously foul, and the teeth were in good condition.

The respiratory system showed nothing abnormal.

The heart (weight $8 \frac{3}{4}$ oz.) appeared healthy.

The liver (weight $102 \frac{1}{2}$ oz.) was enlarged and tough ; on section it was pale, and there were no hæmorrhages or infarcts. The spleen (weight 53 oz.) was much enlarged and of firm consistence ; it contained numerous large infarcts, some of which were breaking down and softening; most were recent, and none of old standing. No free iron reaction was obtained. The kidneys (weight $11 \mathrm{oz}$.) were pale, and showed a few small hæmorrhages. The intestines were normal.

The lymphatic glands of the neck, axilla, and groins, as well as the mediastinal and mesenteric glands, were enlarged and firm, with a pale colour on section.

The thymus (weight $210 \mathrm{oz}$ ) was enlarged, and extended up to the lower margin of the thyroid gland ; it appeared normal on section.

Histological Fxamination.-Spleen.-There was no thickening of the capsule, but the cellular infiltration into and beneath it was very marked. Hæmorrhages were abundant, and a large area of infarction was seen in the 
sections. Malpighian bodies were ill defined. The lymphocytes, and especially the large lymphocytes, formed the majority of the cells; the remainder consisted of large hyaline, transitional, endothelial cells, and a few giant cells. No pigmentation was seen, and there was no evidence of phagocytosis. The blood vessels were filled with cells of the same character as those in the pulp.

Lymphatic gland.-Slight thickening of capsule was present. The predominant cells were lymphocytes, but small numbers of transitional neutrophils, endothelial, and finely granular polynuclear cells were scattered throughout the gland tissue. The capsule of the gland was infiltrated with lymphocytes, and small collections of these cells were found in the adipose tissue in which the gland was embedded. The "germinal centres" were ill defined, and the cells in these areas were sinilar to those in the rest of the gland. There was well-marked mitosis, chiefly affecting the small lymphocytes and transitional cells.

Thyroid.-Some vesicles were dilated, others collapsed, and containing little or no colloid. The capillaries were distended with lymphocytes, both small and large.

Kidne?. - There was no thickening of the capsule, but some lymphocytic infiltration was observed throughout the renal tissue. The epithelium of the convoluted tubules was healthy, but in the straight tubules it was ragged, and many of the cells had lost their nuclei. The walls of Bowman's capsules were infiltrated with lymphocytes, but the epithelium of the capsule was intact. The glomerular tufts were partially filled with lymphocytes. The lymphocytic infiltration in the cortex of the kidney was very abundant, causing compression of the tubules, and separating them from each other by wide intervals. Mitotic figures in the small lymphocytes were numerous, and a few of the cells showed fragmentation of the nuclei.

Liver.-The capsule was infiltrated with lymphocytes, but did not show any evidence of fibrosis. There were wide areas of cellular infiltration in the portal spaces, separating the hepatic lobules, and extending inwards between and among the liver cells. The exudate was found to be composed almost entirely of small and large lymphocytes and some transitional cells. No endothelial cells were found. The hepatic cells showed no signs of vacuolation or other evidence of degenerative changes.

Hamolymph gland.-The capsule was normal. Well-formed blood vessels were present throughout the gland tissue, and red blood cells were scattered in all directions. There was no fibrosis, the reticulum being rather more open than usual. The greater proportion of the cells were non-granular, chiefly large and small lymphocytes, many of them showing mitotic figures. Mononuclear cells with basophil granules were present in small numbers, also a very few mononuclear cells with finely oxyphil granules. Coarsely granular eosinophils were not observed. Very few polynuclear cells were present, but transitional cells with fine oxyphil granules were fairly numerous. Very large endothelial cells were frequently met with throughout the gland. Large wellformed giant cells, some with two or three nuclei, some with more, the nuclei grouped chiefly centrally, and which closely resembled the giant cells of the bone marrow, were present in small numbers. We failed to observe any phagocytic action on the part of these cells. The nucleated red cells numbered about two or three in every microscopic field (examined with $\frac{1}{12}$ oil immersion lens and No. 4 eyepiece); nearly all these cells were normoblasts, and most of them showed evidence of mitosis. No pigmentation was seen anywhere in the gland. Sections of all the viscera were examined for the presence of free iron with negative results.

Result of Examination of BloOD-Date, 14th June 1905.

$$
\begin{aligned}
& \text { Erythrocytes . . . . . 2,620,000 c.mm. } \\
& \text { Hæmoglobin . . . . . } 50 \text { per cent. } \\
& \text { Colour index . } \quad . \quad \cdot \quad \cdot \quad \cdot \quad \cdot \quad \cdot \quad \cdot 0.9 \\
& \text { Leucocytes . } \quad . \quad \text {. } \quad \text {. } 223,600 \text { per c.mm. }
\end{aligned}
$$


Fresh blood.-Rouleaux formation good. Fibrin formation poor. Blood platelets few. Poikilocytosis slight.

Stained Blood.

\begin{tabular}{|c|c|c|c|}
\hline & $\begin{array}{l}\text { Total Number of } \\
\text { Cells counted. }\end{array}$ & Percentage. & Cells per c. mm. \\
\hline \multirow[t]{2}{*}{$\begin{array}{l}\text { Polynuclear neutrophils } \\
\text { Do. eosinophils } \\
\text { Small lymphocytes } \\
\text { Large lymphocytes } \\
\text { Neutrophilic myelocytes : } \\
\text { Coarsely granular basophiles. }\end{array}$} & $\begin{array}{r}39 \\
2 \\
381 \\
567 \\
9 \\
2 \\
0\end{array}$ & $\begin{array}{l}3 \cdot 9 \\
0 \cdot 2 \\
38 \cdot 1 \\
56 \cdot 7 \\
0 \cdot 9 \\
0 \cdot 2 \\
0\end{array}$ & $\begin{array}{r}8720 \cdot 4 \\
447 \cdot 2 \\
85191 \cdot 6 \\
126781 \cdot 2 \\
2012 \cdot 4 \\
447 \cdot 2 \\
0\end{array}$ \\
\hline & 1000 & $\cdots$ & $\ldots$ \\
\hline
\end{tabular}

NOTES ON STAINED BLOOD.

Beven megaloblasts and five normoblasts seen during a count of 1000 leucocytes, Slight polychromatophilia and granular degeneration present. Macrocytes and microcytes numerous. Large numbers of vacuolated and :degenerated mononuclear cells present. All gradations were seen, between small and large lymphocyles, the difierentiation of which was only approximate.

Result of Examination of Bone Marrow (Rib).

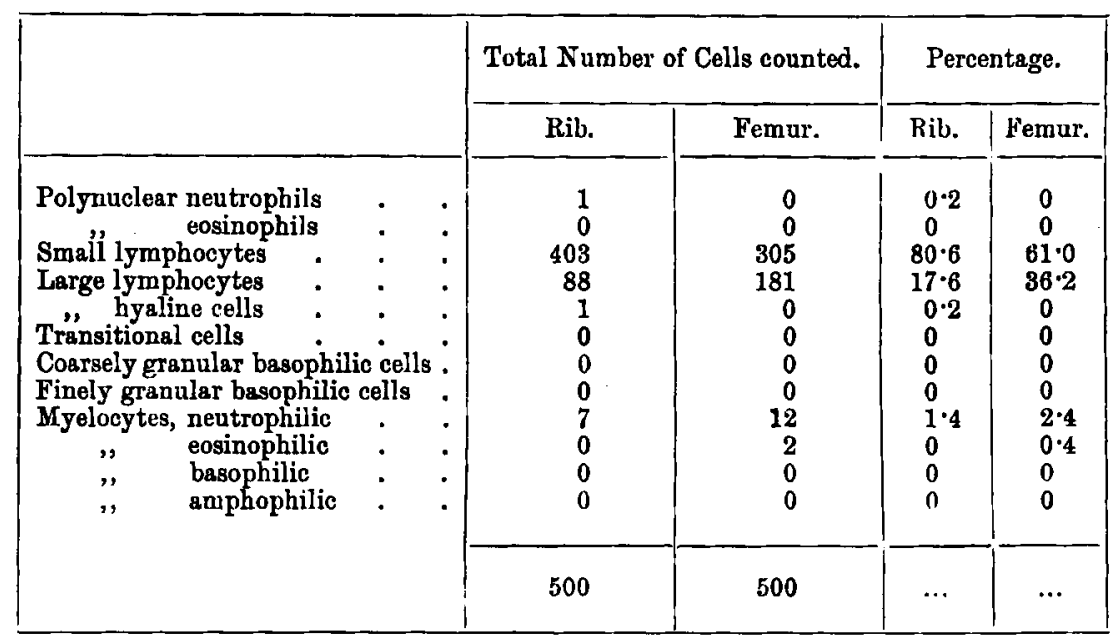

Rib-Three normoblasts and three megaloblasts seen while counting 500 celle. Femur-No nucleated red cells geen.

\section{CASE III.}

Clinical History.-J. S., a boy, at. 11 years, was admitted to St. Thomas's Hospital on 7th March 1906, under the care of Dr. Hawkins.

The family history showed evidence of tuberculous disease on both sides of the family. The past history was uneventful, except for a somewhat serious cut from a septic instrument six months previously.

The present illness was dated from a severe mental shock six weeks previously, followed by a period of moodiness and excitability, and about two weeks later by a painless enlargement of the glands of the neck. Two weeks 
before admission to the hospital the patient complained of pain in the left side and frontal headache, and about the same time he was found to have enlarged glands in the groins and axillæ. Ten days later he noticed spots upon his chest, and began to feel tired and listless. On the day before admission he had a slight attack of epistaxis.

On examination he was found to be a fairly well-nourished boy. The complexion was good, but the mucous membranes were a little pale. The tongue was furred and the breath offensive; the gums were pale and bled on pressure, but were not "spongy." There was a profuse purpuric eruption on the trunk, limbs, neck, and forehead, and a few recent bruises on the legs and arms.

The superficial glands were enlarged all over the body, and varied in size from a walnut to a pea ; they were firm, elastic, painless, and discrete.

The temperature on admission was $101^{\circ} \mathrm{F}$, and the pulse 104 to the minute.

The heart dulness was situated one costal space higher than normal, and a soft "hæmic" murmur was heard over the cardiac area. The lungs were normal. The spleen was firm and hard, and could be felt descending $2 \frac{1}{4}$ inches below the costal margin in the nipple line. The liver dulness began above at the sixth rib in the right nipple line, and extended to just below the costal margin ; its edge could be felt about 1 inch below the ribs.

There was no cedema of the legs. The knee jerks were normal.

The pupil reactions were normal; the retinæ were pale, but the discs were clear and there were no hæmorrhages.

The urine contained a large deposit of urates, and a faint trace of albumin was present.

On 10th March there was a severe epistaxis, accompanied by vomiting. During the next few days the mouth and tongue readily cleared up under treatment, and the patient's general condition improved; at the same time there was a marked decrease in the number of leucocytes in the blood.

From 22nd to 31 st March the purpuric rash gradually faded and the glands became smaller, but the spleen increased in size. There was slight oozing of blood from the nose and gums, and the pulse became more rapid. During this period arsenic was being administered. From this time the patient became weaker and very dreamy there were repeated hæmorrhages from the nose and mouth, and a varying degree of deafness was noticed. Death took place on 9th April.

The temperature throughout varied from $103^{\circ} \mathrm{F}$. in the evenings to $98^{\circ} \mathrm{F}$. in the mornings.

The urine on several examinations was found to contain large quantities of uric acid crystals; blood was never present, and only on one occasion a small trace of albumin.

Post-mortem Examination, by Dr. Box.

Externaluy the body was pallid and sparsely nourished. There was no ulceration of the mouth and tongue.

INTERNALLY the most striking features were the extreme anæmia of all the organs, the uniform enlargement of all lymphatic glands and spleen, the numerous hæmorrhages in the viscera, and the appearance of the blood.

The lymphatic glands throughout the body were enlarged, they were pale and succulent and almost gave the impression of translucency; one or two were so soft that they might almost be termed abscesses. On section the majority showed sccttered pinkish patches contrasting with the yellowish white of the remainder. Only one hæmolymph gland was definitely recognised.

The Spleen (weight $13 \frac{1}{4}$ oz.) was much enlarged, and attached by recent adhesions to the diaphragm; it was firm and fleshy on section.

The pleural and pericardial sacs showed many large hæmorrhagic 
petechiæ; there were no effusions. The Lungs (weight 16 oz.) were of a greyish-yellow colour, and mottled with hæmorrhages. On section numerous hæmorrhagic patches were present and closely aggregated. The thymus (weight $3 \frac{3}{4}$ oz.) was enlarged and surrounded by a cluster of lymph glands; it was firm and yellowish on section, and contained a large number of hæmorrhagic infiltrations. The heart (weight $6 \frac{1}{4} \mathrm{oz}$.) was pale, and its surface freely sprinkled with small petechix. The valves were healthy.

The liver (weight $36 \frac{3}{4}$ oz.) was of normal size; it was pale, of firm consistence, and free from hæmorrhages and infiltrations to the naked eye. The kidneys (weight $12 \mathrm{oz}$.) were large and almost white; numerous circular hæmorrhages were seen both superficially and on section. The mucous membrane of the stomach was speckled with hæmorrhages; that of the duodenum and rest of the intestines was normal. The pancreas was pale, but otherwise normal. The adrenals were light brown, and on section showed no colour distinction between cortex and medulla.

The blood in the great veins was very thin and of a light chocolate-brown colour, rather resembling dirty brown water. No clots were found.

Hisease.

The brain (weight $47+$ oz) was pallid, but showed no other evidence of infiltration of the alveolar walls of both lungs. The capillaries were distended with cells, and there was a considerable cellular exudation into the lumen of the alveoli. In some places these cells were almost entirely lymphocytes, in others they consisted of red cells entangled in a meshwork of fibrin. A large vessel containing an ante-mortem thrombus was seen in the sections.

Thyroid.-Very little change was noticeable. There was slight lymphocytic infiltration under the capsule, and also of the alveolar walls. Colloid was present in normal amount, and the cells lining the vesicles were normal.

Heart.-There was enormous lymphocytic infiltration of the epicardium, extending downwards between the muscle bundles, which were widely separated. There were large scattered areas of fatty change throughout the musculature; the fat globules in some parts were large and coarse, whilst elsewhere many of the muscle fibres showed an excessively fine fatty change. The transverse striation of many of the fibres was either absent or ill defined.

Pancreas.-A small collection of lymphocytes was seen in the gland stroma, but the gland parenchyma and islands of Langerhans appeared to be normal.

Kidney.-The capsule was infiltrated with lymphocytes, and enormous collections of small and large lymphocytes were present, especially around the glomeruli and between the tubules, which were widely separated. The glomeruli themselves and the tubular epithelium throughout the greater part of the organ presented nothing abnormal by ordinary staining methods. Specimens stained with Scharlach. $R$. showed a fine fatty change in the tubular epithelium, most marked in the cortical portion of the kidney.

Spleen.-There was marked thickening of the capsule. The Malpighian bodies were very ill defined. There were large areas of cellular exudation around the blood vessels, consisting mainly of small and large lymphocytes, some of which showed mitotic figures. Fragmentation of nuclei was a very well marked feature in the sections; it was not possible, however, in all cases to determine the nature of the cells in which the change was taking place; some were undoubtedly red blood corpuscles, others white. Endothelial cells and plasma cells were present in small numbers, whilst granular cells and true giant cells were entirely absent. A fair number of nucleated red cells were seen, mostly normoblasts, and a few of them were found to show mitotic figures. There was entire absence of pigmentation; parasites and micro-organisms were not seen, although a careful search was made.

Liver.-There was marked accumulation of small and large lymphocytes in the portal spaces and in the capillaries within the lobules, cansing moderate 
separation of the hepatic cells. A fair number of endothelial cells were seen in these situations. There was marked fatty change in the hepatic cells. No pigmentation was seen.

Homolymph glands.-Small capillaries were present in great number; these were filled with the "ghosts" of red blood corpuscles and lymphocytes. The areas of white cells were almost entirely composed of small and large lymphocytes; mononuclear neutrophil and mononuclear eosinophil (coarsely granular) cells were also present. Endothelial cells were scarce. No basophilic cells were seen. There were a few nucleated red corpuscles, mostly

Results of Examination of Blood.

\begin{tabular}{|c|c|c|c|c|c|c|c|c|}
\hline & \multicolumn{2}{|c|}{ Mar. ${ }^{1 .}, 1906$} & \multicolumn{2}{|c|}{ Mar. 15,1906} & \multicolumn{2}{|c|}{ Mar. 27, 1906} & \multicolumn{2}{|c|}{$\begin{array}{l}\text { A. } \\
\text { April 4, } 1906\end{array}$} \\
\hline 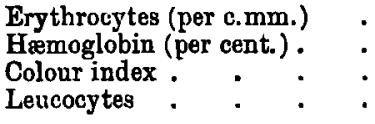 & \multicolumn{2}{|c|}{$\begin{array}{c}3,903,125 \\
50 \\
0 \cdot 6 \\
28,000\end{array}$} & \multicolumn{2}{|c|}{$\begin{array}{c}1,918,750 \\
25 \\
0 \cdot 6 \\
2,680\end{array}$} & \multicolumn{2}{|c|}{$\begin{array}{c}2,540,625 \\
30 \\
0 \cdot 6 \\
31,380\end{array}$} & \multicolumn{2}{|c|}{$\begin{array}{c}1,806,250 \\
25 \\
0 \cdot 6 \\
32,600\end{array}$} \\
\hline 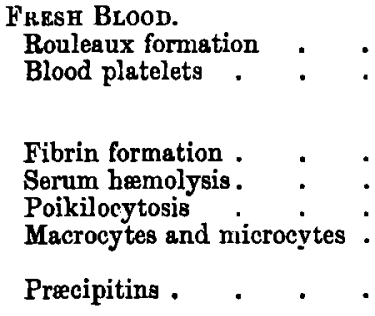 & $\begin{array}{l}\text { Very } \\
\text { Non }\end{array}$ & $\begin{array}{l}\text { slight. } \\
\text {.. } \\
.\end{array}$ & $\begin{array}{l}\text { Norr } \\
\text { Non } \\
\text { Extr } \\
\text { Nur }\end{array}$ & me. & $\begin{array}{l}\text { Feeb } \\
\text { Extr } \\
\text { Nun }\end{array}$ & $\begin{array}{l}\text { le. } \\
\cdots \\
\text { eme. } \\
\text { emous. }\end{array}$ & \multicolumn{2}{|c|}{$\begin{array}{l}\text { Poor. } \\
\text { Agglutination } \\
\text { of red cells } \\
\text { well narked. } \\
\text {... } \\
\text { Present. } \\
\text { Present. } \\
\text { Microcytes } \\
\text { numerous. } \\
\text { Present. }\end{array}$} \\
\hline \multirow[t]{2}{*}{ 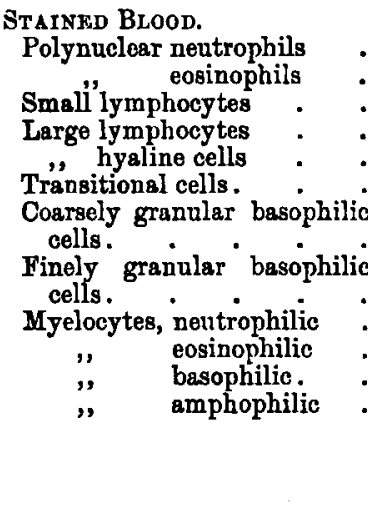 } & $\begin{array}{r}a . \\
7 \\
0 \\
456 \\
35 \\
2 \\
0\end{array}$ & $\begin{array}{r}b . \\
392 \\
0 \\
25,536 \\
1,960 \\
112 \\
0\end{array}$ & $\begin{array}{r}a . \\
27 \\
0 \\
416 \\
39 \\
9 \\
6\end{array}$ & $\begin{array}{r}b . \\
145 \\
0 \\
2,230 \\
209 \\
48 \\
32\end{array}$ & $\begin{array}{r}a . \\
4 \\
3 \\
355 \\
126 \\
8 \\
\ldots \\
\\
\cdots\end{array}$ & $\begin{array}{c}b . \\
251 \\
188 \\
22,280 \\
7,908 \\
503 \\
\ldots\end{array}$ & $\begin{array}{r}a . \\
20 \\
1 \\
384 \\
85 \\
8 \\
\cdots \\
1\end{array}$ & $\begin{array}{c}b . \\
1,304 \\
65 \\
25,037 \\
5,542 \\
522 \\
\cdots \\
65\end{array}$ \\
\hline & 500 & $\cdots$ & 500 & $\cdots$ & 500 & $\cdots$ & 500 & \\
\hline
\end{tabular}

$a=$ Total number of cells counted.

$b=$ Cells per c.mm.

To obtain percentages divide the figure in the first column $a$ by $5-$ e.g. $\frac{7}{5}=1 \cdot 4$, etc.

\section{NOTES ON STAINED BLOOD.}

1. Some macrocytes and microcytes seen, and slight poikilocytosis. Nothing else abnormal detected.

2. Five normoblasts seen in counting $\mathbf{5 0 0}$ white cells. Leucocytes very scarce.

3. Polychromatophilia well marked. Eight normablasts and four megaloblasts seen in counting 500 leucocytes.

4. No nucleated red cells seen. One large hyaline cell had engulfed a red blood corpuscle. Polychromatophilia slight. Blood plateleta scarce. 
normoblasts, present. Mitotic figures and fragmentation of nuclei were only found in a few instances.

Sections of all the viscera were examined for the presence of free iron, with a negative result.

Result of Examination of Bone Marrovo (Rib).

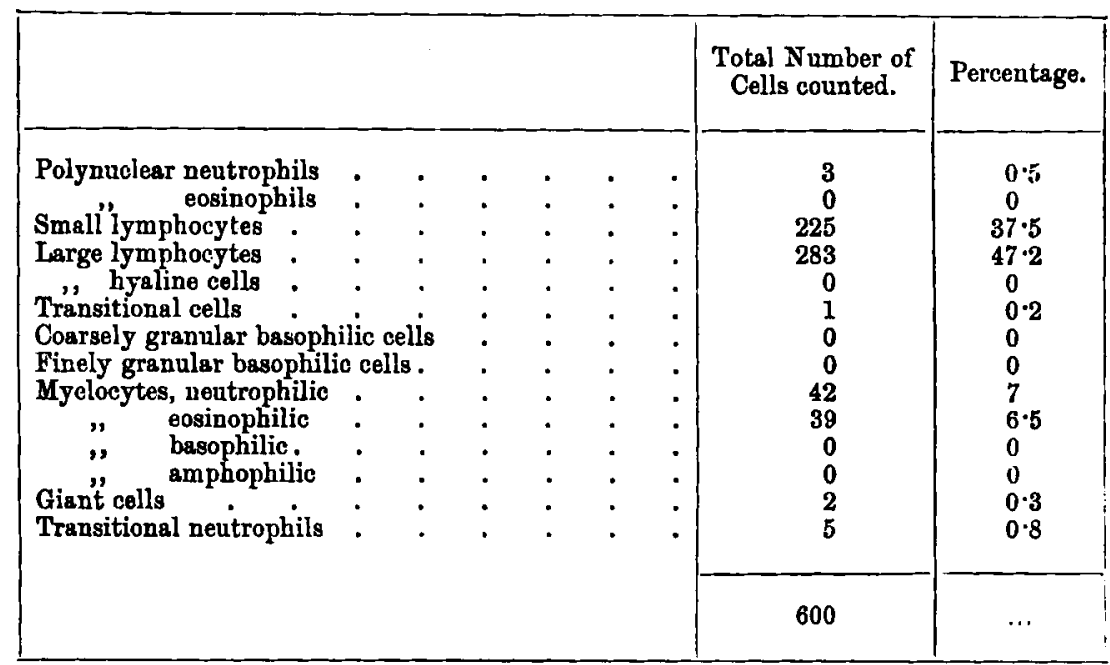

Seven normoblasts and twelve megaloblasts seen while counting 600 cells.

Further examination of blood and tissues. - Two days after admission 10 c.c. of blood were withdrawn from an exposed vein of the arm into a flask containing 150 c.c. of broth. A pure culture of a white staphylococcus was obtained; this was passed through Mervyn Gordon's media for the differentiation of cocci, and was found to differ in several points from the white micrococcus found to be present in the tissues of malignant cachexia by Doyen.

Five c.c. of citrated blood obtained in a similar manner were added to a tube of normal saline and incubated at $22^{\circ} \mathrm{C}$. for several weeks, but without result.

An enlarged superficial lymphatic gland was aspirated during life, and film preparations made from the scanty fluid obtained. No parasites were seen; only small lymphocytes were present.

A bacteriological examination of the spleen was made seven hours after death, and a pure culture of staphylococcus aureus was obtained. No parasites were seen in film preparations. Portions of spleen were added to sterile tubes of citrate of soda and incubated at $22^{\circ} \mathrm{C}$. with a negative result.

\section{Résumé.}

Cuinical Histories.-The three patients were young males between the ages of 11 and 19. The first symptoms noticed occurred in two cases three weeks before admission to hospital, and in one case six weeks. The periods during which the patients remained under observation were two months, three days, and three months respectively.

In Case 2, although the patient was admitted in a dying condition, 
the mouth was in a fairly clean state, and at the post-mortem examination no evidence of oral sepsis was found. In Cases 1 and 3 there was some foetor of the breath associated with the hæmorrhage from the nose and mouth, but in neither case was there any true oral sepsis. In none of these examples, therefore, could any septic condition of the mouth be considered to have been an important factor in the disease. In each instance hæmorrhages into the skin and from the mucous surfaces were a prominent feature; in one case there was bleeding from the kidneys.

There was enlargement of the liver, spleen, and lymphatic glands in the three cases.

All the patients had marked pyrexia.

AUTOPSIES.-Capillary hæmorrhages were present in each instance, and in one case were a very striking feature throughout the body.

In Case 2 the spleen contained numerous large infarcts.

The lymphatic glands throughout the bodies were increased in size, and in two cases also were softened.

Only one hæmolymph gland was definitely recognised in the three autopsies.

The spleen in each body was enlarged and tough; in Case 2 it had attained enormous dimensions. There was a proportionate enlargement of the liver in each instance.

The thymus was greatly enlarged in two cases.

On the whole the pathological changes recognisable to the naked eye were slight when compared with the microscopical findings.

Histological Examination of Principal Viscera.-In every instance the striking feature of the microscopical anatomy was the leucocytic infiltration of the various viscera, although in Case 1 this was less obvious. The vast proportion of the cells met with were large and small lymphocytes. Mitosis was observed in the lymphocytes, but not to any marked extent. Coarsely granular eosinophil cells were almost entirely absent. A few plasma cells were seen in Case 1 in each viscus, but in the other cases none were present.

Only the cardiac muscle and kidney of Case 3 were examined for the presence of fat, and in these specimens fine fatty change was well marked.

In every case all the viscera were examined microscopically for free iron, with negative results.

In none of the viscera were any micro-organisms or parasites seen.

BONE MARRow.-The great preponderance of non-granular over granular cells is well shown in the accompanying table. Of the nongranular cells, the great proportion were large and small lymphocytes. In the rib marrow of Case 2 there were 80.6 per cent. of small lymphocytes and 17.6 per cent. of large lymphocytes, whereas in the femur marrow there were 61 per cent. of small and 36.2 per cent. of 
large; in Case 3 the small lymphocytes amounted to $37 \cdot 5$ per cent., whilst the large were $47 \cdot 2$ per cent. (in the rib marrow).

The finely granular polynuclear neutrophils were extremely scarce in each instance, even less than in normal bone marrow.

The neutrophilic myelocytes were almost entirely replaced by the non-granular cells; yet in Case 3 the eosinophilic myelocytes amounted to 6.5 per cent., an even larger proportion than is found in normal bone marrow. No coarsely granular polynuclear eosinophils were seen.

No giant cells were seen while examining the films of rib and femur marrow of Case 2, and in Case 3 they amounted to 0.3 per cent.

Nucleated red cells were scanty.

HжмоLYмPн GLANDS.-The hæmolymph glands of Cases 2 and 3 furnished a striking contrast. In the former instance the structure was almost identical with that of bone marrow, giant cells being present, indistinguishable from those of bone marrow, and nucleated red cells in large numbers, chiefly normoblasts, most of which showed evidence of mitosis; the greater proportion of the cells, however, were non-granular. No phagocytosis on the part of the giant cells was observed. In Case 3 the structure was very similar to that of a lymphatic gland, giant cells being absent, while nucleated red cells were very few, and for the most part normoblasts.

Comparative Table of Granular and "Non-granular" Cells in Bone Marrow and Blood (examined a few days before death).

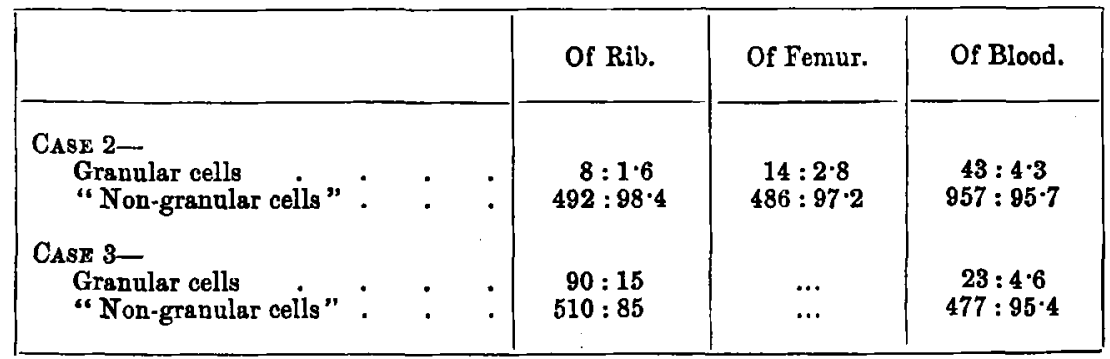

The BLoon. - The erythrocytes and blood serum.-A striking feature in the examination of the blood in Cases 1 and 2 was the high colour index. In the former instance this was so marked as to simulate pernicious anæmia. In Case 3 the colour index was that of a secondary anæmia.

The number of red cells was considerably reduced in all cases, and in one instance fell below 1 million. Although in Case 1 the colour index resembled that of pernicious anæmia, yet the erythrocytes remained above 2 million, except at one examination.

The number of megaloblasts and normoblasts in Case 1 is unusual.

32-Tx. Of PATH, TOL. $x$. 
Agglutination of the red cells was observed at the last examination of the blood in Cases 1 and 3, and in the latter case præcipitins and hæmolysins were present on the same occasion. Blood platelets were scarce in every instance.

The LeucocyTms.-Case 1 and 2 were characterised by a steady increase in the total number of leucocytes as the disease progressed, interrupted by a temporary improvement in Case 1 after X-ray treatment, and by a period of leucopenia in Case 3, for which no cause could be assigned. In case 2 only one blood examination was possible, and here the leucocytes reached 223,000 per c.mm., the highest count in the series. In Cases 1 and 3 there was a slight gradual increase in the proportion of large lymphocytes, whilst in Case 2 they greatly outnumbered the small lymphocytes.

In Case 1 the blood at the outset was quite unlike anything previously recorded in acute lymphocythæmia, the large hyaline cells and the finely granular polynuclear cells comprising from 80 to 90 per cent. of the white cells. In the last fortnight of life the large hyaline cells were replaced by the large and small lymphocytes, the finely granular polynuclear cells remaining still at an unusually high figure. The large hyaline cells contained large and coarse vacuoles, more especially when these cells were present in large numbers. The large majority of the polymorpho-nuclear cells were nongranular.

In the entire series of cases only one mast cell was seen.

In Case 1 the coarsely granular eosinophils were considerably increased; in the other cases they were much below the normal.

In all cases the neutrophilic myelocytes were present in very small numbers, as may occur in any case of anæmia.

A differential count of the white cells in Case 1 gave an almost identical result with both Ehrlich's and Leishman's stains.

\section{REMARKS.}

In bringing forward these three cases an attempt has been made to give as complete an account as possible of an obscure affection. Very little light is thrown upon the etiology of the disease, nor can it be said that any support is lent to the view that oral sepsis is an important etiological factor. A careful search was made for parasites both in the blood and tissues; and attempts at cultivation were made by the method of Leonard Rogers, but no animal parasites were found. In one case a white staphylococcus was obtained from the blood during life, and a staphylococcus aureus from the spleen at the autopsy; but little or no importance can be attached to the presence of these cocci in the terminal stages of an acute infection.

The three cases apparently ran an acute course, and seem to represent the commoner type of the disease, since no instance of 
chronic lymphæmia has been met with at St. Thomas's Hospital of recent years. The reverse holds good in myelæmia, which in almost all instances is a chronic disease. It would be convenient here to consider whether acute lymphæmia represents the acute type of myelæmia ; such evidence as we possess appears to us entirely opposed to this view. The great diminution in the number of erythrocytes; the eomparatively small number of nucleated red cells; the less obvious increase of leucocytes, the large proportion of which are lymphocytes; the absence of mast cells; the rarity of coarsely granular eosinophil cells; the scarcity of the neutrophilic and eosinophilic myelocytes, with the complete absence of the basophilic and amphophilic varieties - all these points give a completely different picture in the blood alone.

In the bone marrow in lymphæmia there is no naked-eye change, while in myelæmia there is an enormous increase of the red marrow. In two of our cases of lymphæmia, in which we were able to examine the bone marrow, the cells were found to consist almost entirely of non-granular lymphocytes, and nucleated red cells were very scarce; in myelæmia all varieties of granular and non-granular cells, and large numbers of nucleated red cells, are met with.

In the tissues in lymphæmia the infiltrations by non-granular cells are much more marked then in myelæmia.

Recently, attention has been drawn to a disease called leukanæmia, in which there are found changes in the red cells corresponding to those of pernicious anæmia, and in the white cells to those of leukæmia, while there is also an infiltration of the viscera by leucocytes. In Case 1 of our series there were certain changes in the blood similar to those of pernicious anæmia, more particularly the high colour index, the large number of megaloblasts, and the deficiency of blood platelets; while the changes observed in the white cells were similar to those found in lymphæmia. But we do not consider there is sufficient evidence in this case to warrant its differentiation from other cases of leukæmia.

It has been suggested that the degree of anæmia depends upon the power of the white cells to engulf the red-blood corpuscles, the latter having been previously prepared by the action of the patient's serum. In all the examinations of the blood in this series only one red cell was seen to have been so engulfed. Although in some of the recorded cases of lymphocythæmia hæmolytic changes have been demonstrated in the tissues, and while in Case 3 the patient's serum showed evidence of hæmolysis five days before death, yet the microchemical tests for free iron were absent in this as in the other instances.

If we compare the cytological characters of the bone marrow with those of the blood we find a result very similar in each instance. The predominant cells in the blood and bone marrow are the lym- 
phocytes, both large and small. In the table on p. 473 the comparative results of the differential counts of blood and marrow are recorded. It will be seen that in Case 2 the number of non-granular cells was very similar in both tissues, while in Case 3 the non-granular cells in the blood were more numerous by about 10 per cent.

The main result obtained from this investigation is that the majority of the cells throughout the body are lymphocytes; this is very clearly shown in those instances in which differential counts were made of the most important tissues.

Although we have used the term " non-granular cells," and even referred to the lymphocytes as non-granular, we are fully alive to the fact that this statement is not strictly accurate. One of us (L. S. D.) has already drawn attention to the presence of small basophilic granules in the lymphocytes both in normal and pathological blood, and has already shown diagrams of the blood in acute lymphocythæmia, in which many lymphocytes contained these fine granules. ${ }^{1} \mathrm{He}$ has observed definite eosinophilic granules in the large lymphocytes in both normal and pathological blood, quite apart from eosinophilia, in a few instances. It is, therefore, hardly accurate to classify the white cells of the blood into "granular" and "non-granular," as probably all varieties of cells are granular to some extent. Although only a small proportion of the small and large lymphocytes and large hyaline cells in normal blood may be found to be granular, yet in acute lymphocythæmia many contain granules; this is probably due to the large numbers of cells seen.

It is of considerable importance to explain these points to which we have just referred, chiefly because of the interest which concerns the relationship of the granular and the "non-granular" cells. The lymphocytes in lymphocythæmia vary considerably in size, so that any hard and fast division into large and small lymphocytes can only be approximately correct. It has been suggested that these cells are not really lymphocytes, but either cells absent from normal blood or else. neutrophilic myelocytes. The latter idea has nothing to support it either from the practical or theoretical standpoint, as the complete examination of the tissues in these cases helps to show ; but the former question is of great interest, although certainly speculative. It does not seem extraordinary, however, in acute lymphocythæmia that the lymphocytes should vary in size to such an extent as to lead to this view when we consider the rapidity of the disease; even the "myelocytes" of all kinds and the "non-granular" cells in chronic myelæmia are of extremely variable size. Until actual proof is forthcoming one way or the other it seems advisable to allow the predominant cells in acute lymphocythæmia to be classified as lymphocytes.

In conclusion, these cases which we have studied give support to

1 "Acute Lymphocythæmia," Trans. Path. Soc., London, 1905, vol. lvi. part 2. 
those who hold that acute lymphocythæmia is a special entity, and not really acute myelæmia, and that there is no evidence, as yet, to show that acute lymphocythæmia is a parasitic disease.

We offer our thanks to Drs. Sharkey and Hawkins for permission to make use of the entire clinical and pathological material obtained from the cases under their care.

\section{DESCRIPTION OF PLATE XXXIV.}

FIG. 1.-Film of rib bone marrow from Case 2. The cells seen in the field are almost entirely small lymphocytes and red cells, with a few large lymphocytes. No granular cells and no nucleated red cells are seen. Filmg stained with Leishman's stain. Zeiss, $\frac{1}{12}$ oil immersion obj., and eyepiece "B."

Fic. 2. Section of liver from Case 2, showing enormous collections of large and small lymphocytes in the portal speces and between the columns of hepatic cells. Stained with hæmalum and eosin. Zeiss, obj. " $\Delta$," and eyepiece " B."

FrG. 3. - Section of the cortex of the kidney from Case 2, showing wide separation of the tubules by collections of small and large lymphocytes. Stained with hæmalnm and cosin. Zeiss, obj. "A," and eyepiece "B."

FIa. 4. - Section of heart wall and epicardium from Case 3, showing fine fatty change in the cardiac muscle and extensive lymphocytic infiltration of the epicardium ; the large fat droplets seen in the latter are of course normal. Stained with Scharlach. R. and hæmalum. Zeiss, obj. " $D$," and eyepiece "B." 


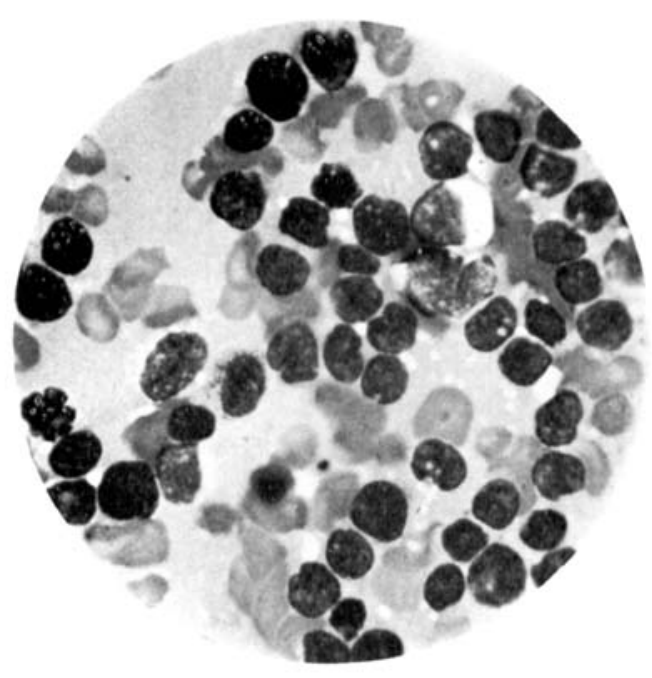

Fic. 1.

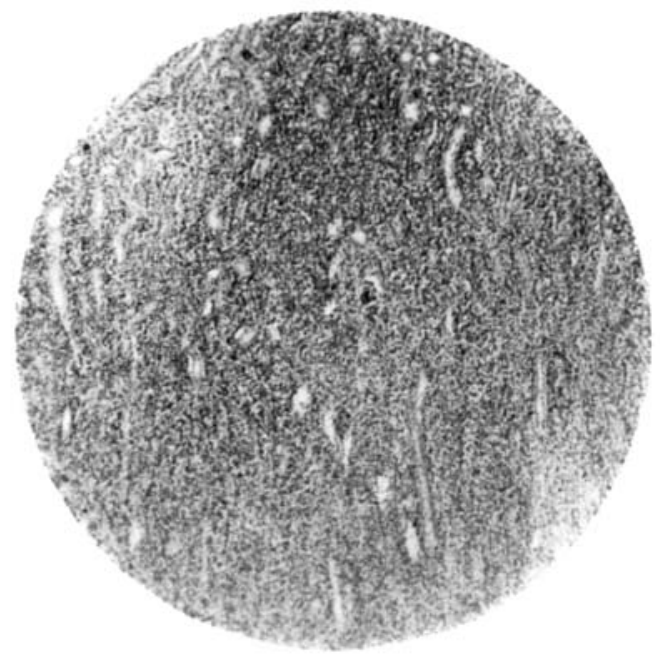

Fic. 3.

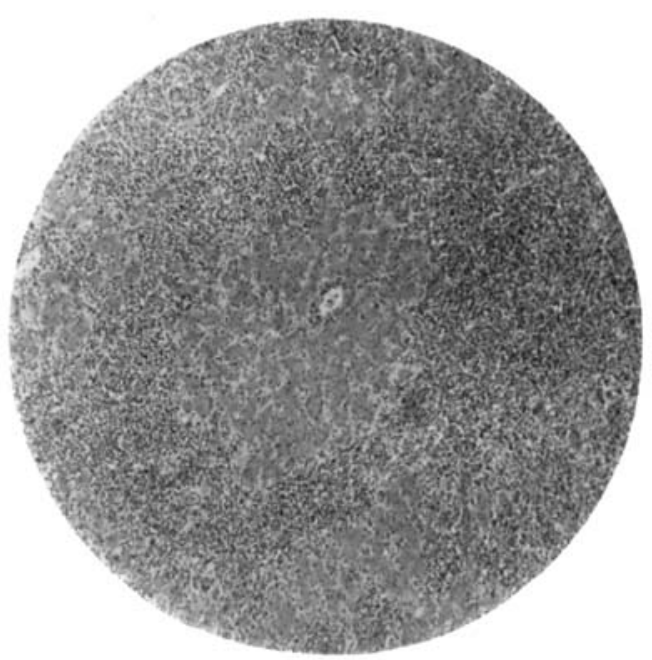

Fig. 2.

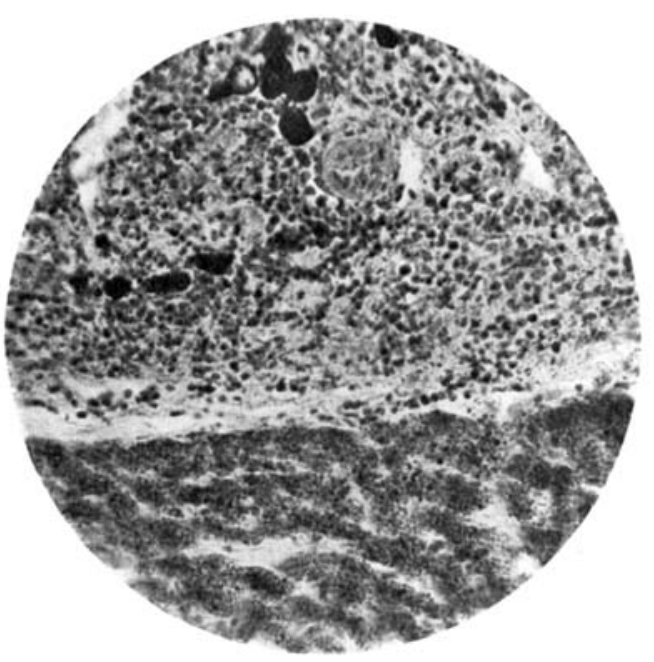

Fig. 4, 